\title{
A new model of secondary prevention of cardiovascular disease in patients after acute coronary syndrome
}

\author{
Nowy model wtórnej prewencji chorób sercowo-naczyniowych \\ dla pacjentów po przebytym ostrym zespole wieńcowym
}

\begin{abstract}
Andrzej Pająk
Department of Epidemiology and Population Studies, Institute of Public Health, Faculty of Health Sciences, Jagiellonian University Medical College, Krakow, Poland
\end{abstract}

In "Kardiologia Polska" the authors Dariusz Dudek, Zbigniew Siudak, and Svein Solheim published an article "New model of secondary cardiovascular prevention for patients after acute coronary syndromes in Poland with regard to Norwegian experiences" [1]. In the article they briefly described the model of secondary prevention of cardiovascular disease (CVD) the implementation of which has been launched in 13 interventional cardiology centres in Poland [1]. It is an ambitious and extensive initiative that is worth attention and a short commentary.

Coronary artery disease is a chronic condition and the treatment of patients who have had acute coronary syndrome (ACS) or have been treated invasively does not end in the hospital. In Poland, after being discharged from hospital, $12 \%$ of ACS patients are hospitalised again within a year, and among those who have had a myocardial infarction (MI) 10\% die within one year after discharge from hospital [2]. Lifestyle modification, regular medications' intake, and cardiac rehabilitation can prevent subsequent CVD events and reduce the risk of death. Whereas, the better the quality of health care (including compliance with current guidelines and reliance on the indicators of the quality), the greater the effectiveness of prevention. Patients who were advised sub-optimal medical therapy at discharge from hospital have been found to have had worse prognosis at one-year follow-up [3].

Cardiac rehabilitation after hospitalisation for ACS, which is carried out in specialised centres, facilitates long-term use of optimal therapy through patient education and repeatedly emphasising the importance of the continuation of taking prescribed medication and maintaining the recommended lifestyle changes. Post-ACS cardiac rehabilitation is considered a strategy which improves prognosis, reduces the frequency of hospital re-admissions increases life span, and which is cost-effective and reduces healthcare expenditures. According to the current guidelines on secondary prevention, all CVD patients must receive clear therapeutic recommendations based on scientific evidence, and all ACS patients should participate in a cardiac rehabilitation programme. It is also recommended that coronary disease patients be included in a formalised cardiac prevention and rehabilitation programme [4, 5].

Traditionally, there are two main types of rehabilitation programmes: hospital-based and outpatient. Recently, attention has been given to hybrid programmes (combined hospital-based and outpatient rehabilitation) and to programmes co-ordinated by nurses [4-6]. Nurse-led clinics and multidisciplinary prevention programmes co-ordinated by nurses were more efficient compared with usual care in terms of reducing cardiovascular risk in a variety of conditions of providing care, provided that they were well-integrated within the operating systems $[4,5]$. New solutions are also being discussed. For example, patients with coronary artery disease could participate in self-help programmes, programmes offered via the Internet, or based on smartphone applications.

In general, it is accepted that health education and exercise programmes should be essential components of health programmes that should be provided to patients with coronary artery disease, especially those after ACS. However, there is uncertainty as to the ultimate outline of the cardiac education and rehabilitation programme in order to maximise the benefits from secondary prevention. For example, the optimal duration of the cardiac rehabilitation programme remains unknown; it is also necessary to determine the optimal (and the most cost-effective) intensity and duration of the individual components of the programme in order to reduce long-term 


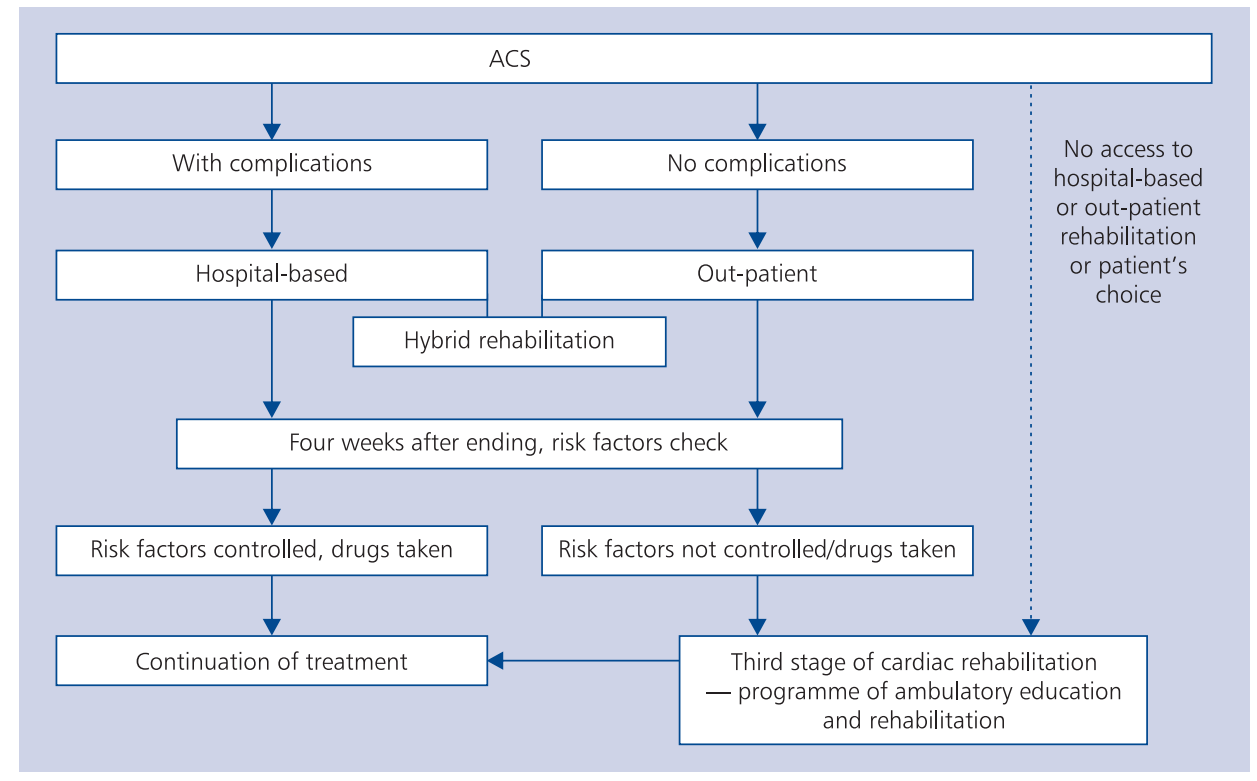

Figure 1. "The Optimal Model of Comprehensive Rehabilitation and Secondary Prevention" in patients after acute coronary syndrome (ACS); according to [5]

risk in patients in the high-risk group. Furthermore, there is a need to determine the extent of knowledge and skills needed to conduct effective prevention programmes, as well as the scope of training required to ensure competency in this area. There is still no quantitative assessment of the extent to which the measures taken to ensure the optimal treatment at discharge from hospital improve the long-term continuation of secondary prevention and cause greater reduction of the incidence of cardiovascular events [4, 5].

In Poland, the National Health Fund assures funding for hospital-based and out-patient cardiac rehabilitation [7]. The number of benefits contracted by the National Health Fund expressed as a percentage of the total number of ACSs and cardiac surgery in Poland varies largely. In particular provinces it was found to be between $0 \%$ and $51 \%$, and on average $18 \%$ [8, 9]. In 2014, the expert group of the Polish Society of Cardiology developed a document titled "The Optimal Model of Comprehensive Rehabilitation and Secondary Prevention", in which, in addition to the opportunities provided by the National Health Fund for ACS patients, it mentioned a third means of cardiac rehabilitation, i.e. a programme of outpatient education and rehabilitation was proposed (Fig. 1) [8]. This proposal meets the requirements of the European Society of Cardiology concerning providing care by nurse-led teams and takes into account the experiences of the only programme of this type so far, which was carried out in Poland in 2004-2006 [10, 11].

Unfortunately, the implementation of European and Polish guidelines into clinical practice is difficult, and reaching the treatment targets in all patients who could achieve them using the available methods is a matter for the relatively distant future. The implementation of prevention methods into the health care system is a rather chaotic process, and it takes place at a much slower pace than desired. In an observational study involving 5353 patients hospitalised with MI it was found that at discharge from hospital only approximately $50 \%$ of patients were under optimal conservative therapy consistent with current standards [3]. In another study, carried out in cardiac centres from 23 European countries, the percentage of coronary heart disease patients who were proposed to participate in an education and/or rehabilitation programme exceeded $70 \%$ in only five centres. In the Polish part of this study, which was conducted in patients after hospitalisation in the Krakow cardiology departments, one of the lowest rates was found, i.e. 34\% (Fig. 2) [12]. The latter finding is alarming. Firstly because the percentage has not changed significantly over the last 15 years. [13]. And secondly because, compared to the whole country, it seems to be quite high anyway. According to the report based on an integrated database on $\mathrm{MI}$, in Poland the average percentage of patients after $\mathrm{MI}$, who participated in the rehabilitation programme, was only $22 \%$ [2].

In Poland the model of secondary prevention of CVD in patients after ACS proposed by the team led by Prof. Dariusz Dudek, the outline of which was published in "Kardiologia Polska" [1], is a valuable initiative that can improve access to secondary prevention. In the construction of the model previous research experience in the field of secondary prevention was used. The model provides a comprehensive approach including raising compliance to drug therapy, reduction of exposure to risk factors, and modification of hazardous behaviours, and it also includes both health education and group exercise. It is very important that the model has a defined structure 


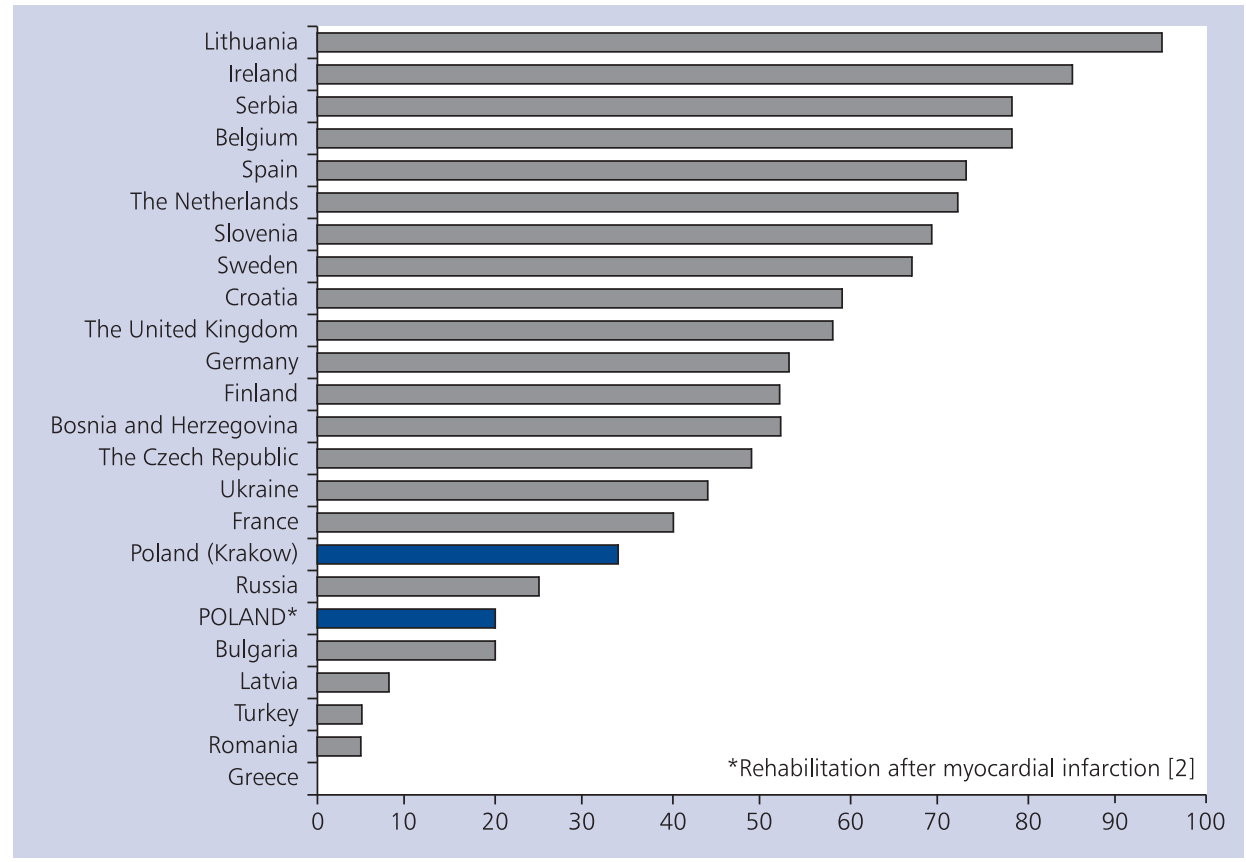

Figure 2. The percentage of patients hospitalised for acute coronary heart disease, who were offered participation in the prevention or rehabilitation programme within three months of being discharged from hospital; according to [2], [12]

and a schedule of activities, and is planned to be led by an interdisciplinary team. The exercise programme, which is an integral part of the proposed model, uses Norwegian experience in the field of rehabilitation of patients with heart failure [14]. According to current opinions, the model includes the involvement of life partners of patients. The new value is the strengthening of group support, which is allowed by organisation of patients in the form of a club. The description of the provided forms of intervention does not indicate any measures that would not be acceptable to patients. However, a relatively low participation rate in the early stages of implementation [15] points to the need to monitor and analyse the reasons for refusals, and then to improve the recruitment methods. The model has been adapted by the 13 centres of interventional cardiology in Poland, and the initial experiences so far show that it is feasible [15]. Further implementation of the model into clinical practice requires completing it with a part that would monitor the impact on risk factors at the individual level, i.e. for each patient. A more extensive implementation of the model requires the determination of its effectiveness at the level of the community subjected to intervention. Next, it is necessary to demonstrate the long-term effects at one-year or longer follow-up and finally to show the evidence that the application of the model reduces the number of subsequent hospitalisations and mortality. It is advisable to compare the results of the implementation of the proposed model, including the evaluation of its cost-effectiveness, with other similar actions. Its success also depends to a significant degree on the discipline and consequence in the implementation of the model in everyday clinical practice, and on the extent to which the model would take a stable position in the health service offered by the 13 centres of interventional cardiology.

Conflict of interest: Honorarium for consulting from Amgen; not related to submitted work.

\section{References}

1. Dudek D, Siudak Z, Solheim S. New model of secondary cardiovascular prevention for patients after acute coronary syndromes in Poland with regard to Norwegian experiences. Kardiol Pol, 74: 101-103. doi: 10.5603/KP.a2015.0176.

2. Gierlotka M, Zdrojewski T, Wojtyniak B et al. Incidence, treatment, in-hospital mortality and one-year outcomes of acute myocardial infarction in Poland in 2009-2012 — nationwide AMI-PL database. Kardiol Pol, 2015; 73: 142-158. doi: 10.5603/KP.a2014.0213.

3. Bramlage P, Messer C, Bitterlich $\mathrm{N}$ et al. The effect of optimal medical therapy on 1-year mortality after acute myocardial infarction. Heart, 2010; 96: 604-609.

4. European Guidelines on cardiovascular disease prevention in clinical practice (version 2012). The Fifth Joint Task Force of the European Society of Cardiology and Other Societies on Cardiovascular Disease Prevention in Clinical Practice. Eur Heart J, 2012; 33: 1635-1701.

5. Piąta Wspólna Grupa Robocza Europejskiego Towarzystwa Kardiologicznego i Innych Towarzystw Naukowych ds. Zapobiegania Chorobom Serca i Naczyń w Praktyce Klinicznej. Europejskie wytyczne dotyczące zapobiegania chorobom serca i naczyń w praktyce klinicznej na 2012 rok. Kardiol Pol, 2012; 70: supl. I: 1-100.

6. Pająk A, Kozela M, Jankowski P. Zapobieganie chorobom układu krążenia w świetle nowych wytycznych europejskich towarzystw naukowych. Gdzie zlokalizować programy prewencji? Kardiol Dypl, 2012; 11: 9-16. 
7. https://zip.nfz.gov.pl/ap-portal/user/menu/open@info?view=054 (last access: 7.01.2016 r.).

8. Jankowski P, Niewada M, Bochenek A et al. Optymalny Model Kompleksowej Rehabilitacji i Wtórnej Prewencji. Kardiol Pol, 2013; 71: 995-1003. doi: 10.5603/KP.2013.0246.

9. Gałaszek M, Eysymontt Z. Aktualny stan rehabilitacji kardiologicznej w Polsce. Raport Sekcji Rehabilitacji i Fizjologii Wysiłku Polskiego Towarzystwa Kardiologicznego 2012.

10. Wood DA, Kotseva K, Connolly S et al. Nurse-coordinated multidisciplinary, family-based cardiovascular disease prevention programme (EUROACTION) for patients with coronary heart disease and asymptomatic individuals at high risk of cardiovascular disease: a paired, cluster-randomised controlled trial. Lancet, 2008; 371: 1999-2012.

11. Sovic N, Pająk A, Jankowski P et al. Cost-effectiveness of cardiovascular disease primary prevention programme in a primary health care setting. Results of Polish part of the EUROACTION project. Kardiol Pol, 2013; 71: 702-711. doi: 10.5603/KP.2013.0157.

12. http://www.sha-education.com/Files/Saudi_Prevent2014/008001. pdf (last access: 7.01.2016 r.).

13. The EUROASPIRE Study Group. Lifestyle and risk factor management and use of drug therapies in coronary patients from 15 countries. Principal results from EUROASPIRE II Euro Heart Survey Programme. Eur Heart J, 2001; 22: 554-572.

14. Nilsson BB, Hellesnes B, Westheim A, Risberg MA. Group-based aerobic interval training in patients with chronic heart failure: Norwegian Ullevaal model. Phys Ther, 2008; 88: 523-535.

15. Siudak Z, Wysocki T, Pers M et al. Skuteczność opartego o edukację programu prewencji wtórnej dla chorych hospitalizowanych z powodu ostrego zespołu wieńcowego w Polsce. Program Klubu Pacjenta. Kardiologia Prewencyjna 2015, Kraków 20-21 listopada 2015, U09.

Cite this article as: Pająk A. A new model of secondary prevention of cardiovascular disease in patients after acute coronary syndrome. Kardiol Pol, 2016; 74: 399-402. doi: 10.5603/KP.2016.0052. 